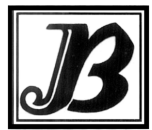

J. Bio-Sci. 23: 1-17, 2015

ISSN 1023-8654

http://www.banglajol.info/index.php/JBS/index

-Review Article

\title{
TREND IN ENZYME IMMOBILIZATION ON NANO MATERIALS FOR TRANSESTERIFICATION TO PRODUCE BIODIESEL: A REVIEW
}

\author{
N Hindryawati ${ }^{1}$, GP Maniam ${ }^{1}$, CK Feng ${ }^{1}$ and MR Karim ${ }^{*} 1,2$ \\ ${ }^{1}$ Faculty of Industrial Sciences and Technology, Universiti Malaysia Pahang, Kuantan, Malaysia \\ ${ }^{2}$ Departent of Biochemistry and Molecular Biology, University of Rajshahi, Bangladesh
}

\begin{abstract}
Biodiesel is a non-toxic and very low sulfur containing, renewable and biodegradable diesel fuel substitute with low volatility and high cetane number. It is derived from fresh or waste vegetable oils and animal fats transesterified with short chain alcohol such as ethanol or methanol in the presence of a catalyst. Several new types of carriers and technologies have been adopted in the recent past to improve the ability of a catalyst in transesterification. One of the new trends is nanoparticles-based immobilization of enzyme as a catalyst. The combination of the precise physical, chemical, optical and electrical properties of nanoparticles with the specific recognition site or catalytic properties has led them to appear in a myriad of novel nanomaterial application. Enzyme immobilized on nanoparticles showed a broader working temperature and $\mathrm{pH}$ range and thermal stability than the native enzyme. Enhancement in the reactivity of nanocatalysts is associated with their increased surface area, greater concentrations of highly reactive edge, unusual and stabilized lattice planes. The greater activity of nanomaterial immobilized biocatalyst affords operational simplicity, low energy consumption, and greater safety, in the process of transesterification. This review article highlights the issues including the exploration of the ability of nanomaterial to immobilize biocatalyst and factors that influence the activity of biocatalysts upon immobilization.
\end{abstract}

Key words: Biodiesel, Immobilization, nanomaterial, transesterification

\section{Introduction}

The issue of worldwide energy consumption has steadily increased, claiming higher budget for living, increasing transportation, industrial and petrochemicals. Fig. 1 shows that the majority of the consumed energy is provided by fuel in the world. Global energy consumption in 2010 rebounded strongly in all regions, driven by economic recovery. The world energy consumption growth reached $5.6 \%$ in 2010 , the highest rate since 1973. After falling for two consecutive years in 2008 - 2009, global oil consumption grew by 2.7 million barrels per day (b/d), or $3.1 \%$, to reach a record level of 87.4 million b/d. Although this was the largest percentage increase since 2004, the worldwide oil consumption growth rate started declining and remained the weakest among all fossil fuels till 2011 and grew slowly again in 2016 - the third consecutive year in which demand has grown by $1 \%$ or less - much weaker than the rates of growth world had become used to over the previous 10 years or so (Dudley 2017). As a result, global crude oil production increased by 2.8 million b/d in 2015, led by a 1 million b/d increase in U.S. production. The bulk of the rest of the world's oil production increase came from OPEC, which cumulatively boosted production by 1.6 million b/d over 2015. BP's definition of crude oil "includes crude oil, shale oil, oil sands and NGLs (natural gas liquids - the liquid content of natural gas where this is recovered separately)."

*Author for correspondence: drmrkarim@yahoo.com 


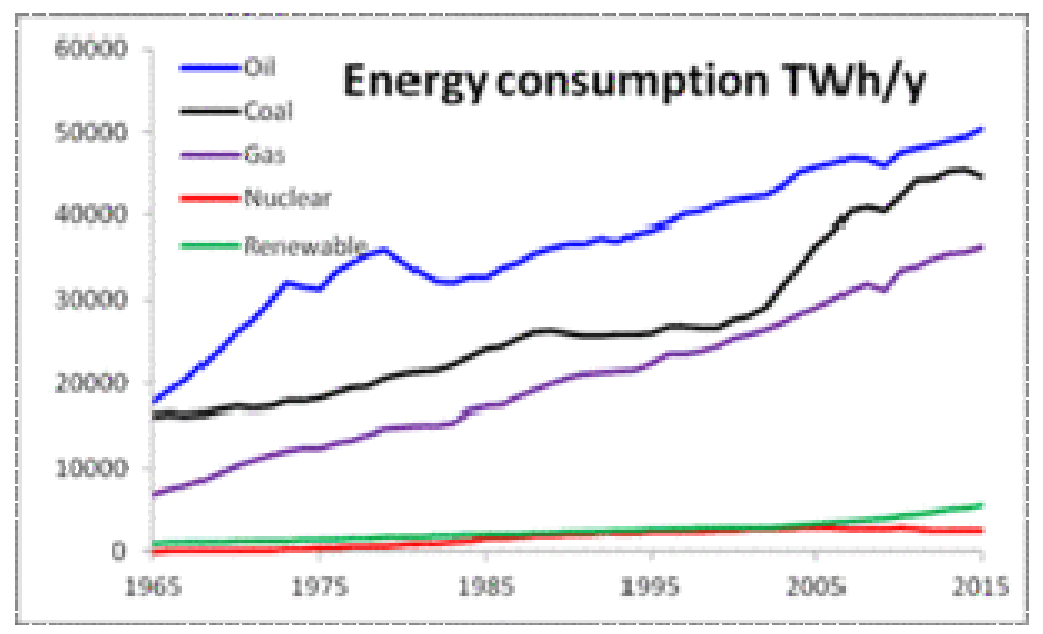

Fig. 1. Global primary energy consumption by fuel 2015.

However, the petroleum is a limited source for fuel that is quickly becoming insufficient and more expensive. In addition, petroleum-based product is one of the main causes of emission of carbon dioxide $\left(\mathrm{CO}_{2}\right)$ to the atmosphere. The transportation sector worldwide is almost dependent on petroleum-derived fuels (Fig. 1). The major causes of global $\mathrm{CO}_{2}$ emissions are transport and industrial sector, which accounts for millions of barrels of oil consumption per day. As in 2015 , the strength in oil demand was most pronounced in consumer-led fuels, such as gasoline. $\mathrm{CO}_{2}$ emission goes up by $0.7 \%$, being trivial in relation to concerns about energy security or climate change (EIA 2011). As a result, there has been a growing interest in alternative source.

Biodiesel is one of the energy sources as an alternative fuel for diesel engines. Biodiesel is defined as a mono alkyl ester, which is produced by transesterification of oil from renewable biological source like vegetable or animal fats. It is an alternative diesel fuel because of its environmental benefits such as being biodegradable, nontoxic and with low carbon dioxide emission profiles (Jegannathan et al. 2010).

In general, there are two prospective methods to produce biodiesel in industrial scale: chemical and enzyme catalyzed method. In chemical-catalyzed method, acid and alkali catalysts can be used (acidic or bases solution) for the production of biodiesel, but there are several drawbacks to this approach, including difficulties in the recovery of the glycerol and potassium and/or sodium salt, and the wastewater treatment problem (Jegannathan et al. 2010, Li et at. 2011). On the contrary, the enzymatic reaction by lipase is a clean technology due to its non-toxic and environment friendly nature. In addition, the process produces high purity grade product and enables easy separation from the by-product, glycerol (Winayanuwattikun et al. 2008).

Lipase is a hydrolytic enzyme, which catalyzes a reversible reaction to hydrolyze triglycerides to free fatty acids and glycerol and the esterification of free fatty acids and alcohol to ester (e.g. biodiesel). So lipase is 
used as industrial biocatalyst (Sangeetha et al. 2011). Much research is needed to overcome problems such as enzyme inhibition by methanol, exhaustion of enzyme activity and high cost of enzymes, which may contribute to the global effort on industrial implementation of the enzymatic production of biodiesel in the near future (Iso et al. 2001, Nordblad and Adlercreutz 2008, Fjerbaek et al. 2009). Immobilization improves the enzyme stability under the reaction conditions, and enhances enzyme activity, thus, makes the repeated use of the enzyme feasible, permits the use of enzyme for diverse applications and thus lowers the production cost (Bajaj et al. 2010, Tan et al. 2010, Sangeetha et al. 2011). Immobilization provides a better environment for enzyme to act and also offers better product recovery (Lee et al. 2006).

Lipase can be immobilized on different porous support materials. Immobilized enzymes are defined as biocatalysts restrained and localized into microenvironment to retain their catalytic properties. Immobilization usually can increase stability and makes the reuse of the enzyme preparation very simple (Twyman et al. 2005). Immobilization is studied using covalent bonding, cross-linking, entrapment, adsorption, and encapsulation. Selection of an immobilization strategy greatly influences the properties of biocatalyst (Iso et al. 2001, Yagiz et al. 2007, Meunier et al. 2010, Xie and Ma 2010).

Nanomaterials constitute novel and interesting matrices for enzyme immobilization. While their high surface to volume ratio is an obvious advantage, their Brownian motion can impact the behavior of enzymes immobilized on these matrices. Such immobilized enzyme systems have been used in both aqueous and low water media for bio catalysis and resolution of race mates (Xie and Ma 2010, Yiu and Keane 2012). This overview examines the behavior of enzymes immobilized on nanomaterials and discusses the results reported with such biocatalyst preparations.

\section{Biodiesel in general}

Biodiesel is mono alkyl esters of long chain fatty acids contained in the renewable natural resources, such as plant, oils and fats (Moser 2009). Biodiesel is obtained from the transesterification of triglycerides with alcohol using an acid or base catalyst. Biodiesel contains no nitrogen or aromatic component and has sulfur content less than $15 \mathrm{ppm}$. Biodiesel has efficiency as a fuel similar to diesel oil and at the same time it is non-toxic, biodegradable, and has a low emission value (Jegannathan et al. 2010). The use of biodiesel can reduce emissions of $\mathrm{HCs}, \mathrm{CO}, \mathrm{PM}$, sulfates, polycyclic aromatic hydrocarbons and nitrated polycyclic aromatic hydrocarbons. Also $\mathrm{NO}_{x}$ emissions increase with the concentration of biodiesel in the fuel (Balat and Balat 2010).

Generally, vegetable oil or animal fats are esters of saturated and unsaturated monocarboxylic acids with the trihydric alcohol glycerol. These esters are called triglycerides, which can react with alcohol in the presence of a catalyst, a process known as transesterification. The simplified form of its chemical reaction is presented in equation: 


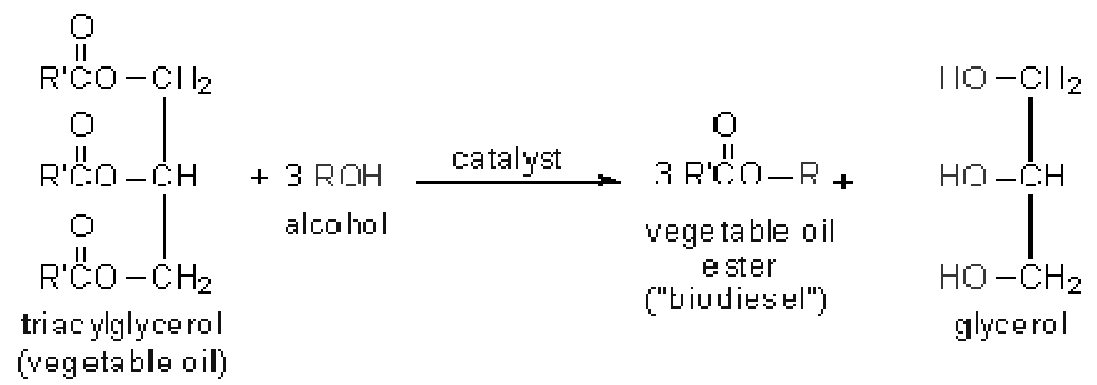

Fig. 2. Transesterification of Triglyceride.

Where, $\mathrm{R}$ in triacylglycerol is long-chain hydrocarbons, sometimes called fatty acid chains. Normally, there are five main types of chains in vegetable oils and animal oils: palmitic, stearic, oleic, linoleic, and linolenic. When a triglyceride is converted stepwise to diglyceride, monoglyceride, and glycerol - one mol of fatty acid is liberated at each step. Usually, methanol is the preferred alcohol for producing biodiesel because of its low-cost (Semwal et al. 2011).

Transesterification, also known as alcoholysis is the reaction of vegetable oil or fat with an alcohol to form esters and glycerol. Stoichiometrically to complete a transesterification reaction a 3:1 molar ratio of alcohol to triglycerides is needed. In practice, to have a maximum yield of esters, this ratio must be higher than the stoichiometric ratio (Leung et al. 2010). A catalyst is usually used to improve the reaction rate and yield. Because the reaction is reversible, excess alcohol is used to shift the equilibrium to the products side.

In transesterification, the alcohol is deprotonated with base to make stronger nucleophile. Commonly, ethanol or methanol is used. As can be seen, the reaction has no other inputs than the triglyceride and the alcohol. Transesterification consists of sequence of three consecutive reversible reactions. The first step is the conversion of triglyceride to diglyceride, followed by the conversion of diglyceride to monoglyceride, and finally monoglyceride to glycerol, yielding one ester molecule for each glyceride at each step. The basic mechanism of transesterification is shown in Fig. 3.

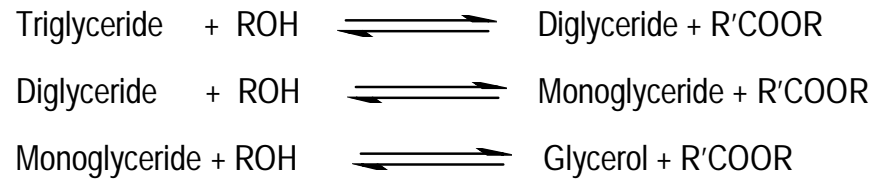

Fig. 3: General equations for transesterification on triglyceride.

The catalyst used for biodiesel production can be grouped as follows base-catalyzed, acid-catalyzed, lipasecatalyzed, heterogeneous catalyzed process.

\section{Homogeneous acid-base catalyzed transesterification}

The homogeneous acid-base catalysis is used if the feedstock contains high FFA. The feedstock first treated with $\mathrm{H}_{2} \mathrm{SO}_{4}$ to reduce the level of FFA to below $1 \mathrm{wt} \%$, followed by transesterification process catalyzed by homogeneous base catalysis. In this method, the yield of FAME is very high but the rate of FFA esterification 
reaction is relatively slow. The drawback to this two-step process is even more pronounced due to the requirement of extra separation steps to remove the catalyst in both stages. Although the problem of catalyst's removal from the first stage can be avoided by using a catalyst from the second stage through the neutralization process, the use of extra base catalyst will add to cost of biodiesel production (Lam et al. 2010).

\section{Homogeneous base catalyzed transesterification}

The base catalyzed transesterification of vegetable oils proceeds faster than the acid-catalyzed reaction. Industrial processes usually favor base catalysts, such as alkali metal alkoxides and hydroxides as well as sodium potassium carbonates. The mechanism of the base-catalyzed transesterification is the reaction of the base with the alcohol, producing an alkoxide and the protonated catalyst (1). The nucleophilic attack of the alkoxide at the carbonyl group of the triglyceride generates a tetrahedral intermediate (2) from which the alkyl ester and the corresponding anion of the diglyceride are formed (3). The latter deprotonates the catalyst, thus regenerating the active species (4), which is now able to react with a second molecule of the alcohol, starting another catalytic cycle (Dias et al. 2008).

Alkali metal alkoxides (as $\mathrm{CH}_{3} \mathrm{ONa}$ for the methanolysis) are the most active catalysts, since they give very high yields (>98\%) in short reaction times, even if they are applied at low molar concentrations. Alkali metal hydroxides $(\mathrm{KOH}$ and $\mathrm{NaOH})$ are cheaper than metal alkoxides, but less active. The presence of water gives rise to hydrolysis of some of the produced ester, with consequent soap formation and reduces the ester yield and considerably difficult to recover the glycerol due to the formation of emulsions. On the other hand, using potassium carbonate gives a high yield of fatty acyl alkyl ester and reduces the soap formation (Chanakya et al. 2013).

\section{Heterogeneous base-catalyzed transesterification}

Base catalysts have been developed for biodiesel production, such as basic zeolites, alkaline earth metal oxides and hydrotalcites. $\mathrm{CaO}$ had attracted much attention due to their relatively high basic strength, low solubility in methanol and can be synthesized from cheap sources like limestone and calcium hydroxide. The yield of FAME was up to $90 \%$ after $1 \mathrm{~h}$ reaction time at methanol reflux temperature and methanol to oil ratio 12:1 (Liu et al. 2008, Son and Kusakabe 2011, Kouzu and Hidaka 2012).

The other research, findings proved $\mathrm{CaO}$ as a potential solid catalyst in transesterifying triglycerides to methyl ester. $\mathrm{CaO}$ requires a thermal activation to remove $\mathrm{CO}_{2}$ and moisture. The research reported that $\mathrm{CaO}$ acts as a heterogeneous catalyst in transesterifying the adsorbed waste palm oil on spent bleaching clay. Compared to the conventional catalysts $(\mathrm{NaOH}$ and $\mathrm{KOH})$, the CaO-catalyzed reaction yielded much higher biodiesel (about 90\%) from the waste cooking oil (6.6 - 6.8\% FFA content) compared to only 46 and $61 \%$ yield using $\mathrm{NaOH}$ and $\mathrm{KOH}$, respectively (Boey et al. 2011a,b).

The reaction mechanism for $\mathrm{CaO}$-catalyzed transesterification is described as the methoxide ion that is attached to the catalyst surface attack the carbonyl carbon of the triglyceride molecule. This results in the formation of tetrahedral intermediate. Then the intermediate is rearranged to form a diglyceride anion and a mole of methyl ester. The charged-anion is then stabilized by a proton from the catalyst surface to form 
diglyceride and at the same time regenerates the catalyst. The cycle continues until all three carbonyl centers of the triglyceride have been attacked by the methoxide ions to give one mole of glycerol and three moles of methyl esters (Boey et al. 2011c).

However, the yield of FAME dropped when waste cooking oil with high FFA was used under the same reaction condition. It is obvious that the basic sites of $\mathrm{CaO}$ were poisoned by strong adsorption of FFA on the surface catalyst. However, the catalytic activity of $\mathrm{CaO}$ can be regenerated if $\mathrm{CaO}$ is subjected to an activation treatment at $700^{\circ} \mathrm{C}$ in order to remove the main poisoning species (the carbonate groups) from the surface. Leaching of the catalyst was still observed in the transesterification reaction, although prior thermal treatment was employed (Lam et al. 2010).

\section{Heterogeneous acid-catalyzed transesterification}

Biodiesel research is focused on exploring new and sustainable solid acid catalyst for transesterification reaction. The advantages of using a solid catalyst are (1) they are insensitive to FFA content, (2) esterification and transesterification occur simultaneously, (3) eliminate the washing step of biodiesel, (4) easy separation of the catalyst from the reaction medium, resulting in lower product contamination level, (5) easy regeneration and recycling of catalyst, (6) reduced corrosion problem, even with the presence of acid species (Semwal et al. 2011).

The ideal solid acid catalyst for transesterification reaction should have characteristics such as an interconnected system of large pores, a moderate to high concentration of a strong acid site, and a hydrophobic surface. The overviews of various solid acid catalysts used $\left(\mathrm{ZrO}_{2}, \mathrm{TiO}_{2}, \mathrm{SnO}_{2}\right.$, zeolite, sulfonic ion-exchange resin, sulfonic modified mesostructure silica, sulfonated carbon-based catalyst, and heteropolyacids) in transesterification reaction that give the high conversion yield of FAME are discussed (Enweremadu and Mbarawa 2009, Petchmala et al. 2010).

\section{Lipase as biocatalyst in transesterification}

Lipase (EC.3.1.1.3, triacylglycerol acylhydrolases) are a group of enzymes, which can hydrolyze triacylglycerols at an oil-water interface to release fatty acids ester and glycerol. The substrates of lipase are triacylglycerols, which have very low solubility in water (Fig. 4). Lipase is present in microorganisms, plant and animals. Lipases catalyze a wide range of reactions, including hydrolysis, trans-esterification, alcoholysis, acidolysis, esterification and aminolysis (Joseph et al. 2008).

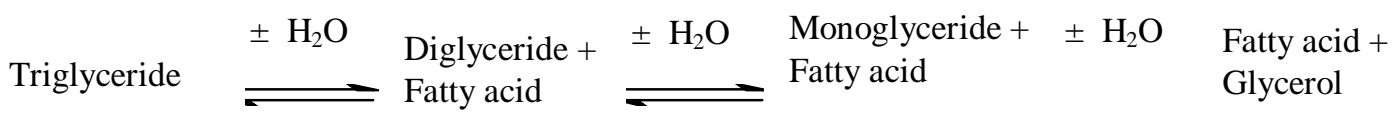

Fig. 4. Lipase catalyzed de-esterification reaction.

Generally, bacterial lipases are glycoproteins but some extracellular bacterial lipases are lipoproteins. The production of extracellular lipase from bacteria is usually dependent on the carbon and nitrogen source, metal salt, chemical reagents, presence of lipids or oil, availability of oxygen, and temperature. The genera of bacteria are Streptomyces sp., Achoromobacter sp., Alcaligenes sp., Arthrobacter sp., Pseudomonas sp. Other than bacteria, many researchers have exploited fungi as valuable sources of lipase due to the following properties: thermal stability, $\mathrm{pH}$ stability, substrate specificity and activity in organic solvents. The fungi that can produce commercial lipase are Aspegillus niger, A. terrus, A. carneus, Candida cylindracea, 
Humicola lanugirosa, Mucor miehei, Rhizopus arrhizus, R. delemar, R. Japonicus, $R$. niveus and $R$. oryzae (Ghosh et al. 1996, Sangeetha et al. 2011).

Lipase from bacteria and fungi are most commonly used for transesterification, and optimal parameters for the use of a specific lipase depend on the origin as well as the formulation of lipase. Based on the result of existing research, lipase from different sources has different properties suitable for the process. Thus, there has been a search for an ideal enzyme (Chen et al. 2009), with screened lipase producing from Candida sp. 99-125 from sewage water in north China has a very high conversion rate in lipase-catalyzed esterification and hydrolysis after several induced mutations. Sangeetha et al. (2011) isolated and screened a total of 360 strains of lipase producing bacteria, yeasts and fungi from the samples of oil-contaminated soil and waste water. Among all the screened microbes, the potential lipolytic bacterium, Staphylococcus warneri, unicellular yeast, Candida rugosa and filamentous fungus, Fusarium solani were selected because of their high specific activities. Table 1 enlists some recently screened lipase producing microorganisms with their substrate and optimum parameters.

Table 1. Different sources of microbial lipase.

\begin{tabular}{|c|c|c|c|c|}
\hline Type & Source & Substrate & Parameter Activity & References \\
\hline \multirow{7}{*}{ Bacteria } & $\begin{array}{l}\text { Pseudomonas } \\
\text { aeruginosa }\end{array}$ & Olive oil & $\begin{array}{l}\mathrm{T}=45^{\circ} \mathrm{C}, \mathrm{pH}=8, \text { max activity }= \\
0.760 \mathrm{U} / \mathrm{ml}\end{array}$ & Mobarak-Qamsari (2011) \\
\hline & $\begin{array}{l}\text { Burkholderia } \\
\text { multivorans }\end{array}$ & Olive oil & $\begin{array}{l}\mathrm{T}=30^{\circ} \mathrm{C}, \mathrm{pH}=9, \text { max activity }= \\
33 \mathrm{Ug}^{-1} \text { protein }\end{array}$ & Gupta et al. (2005) \\
\hline & $\begin{array}{l}\text { Pseudomonas } \\
\text { fluorescens }\end{array}$ & Olive oil & $\begin{array}{l}\mathrm{T}=45^{\circ} \mathrm{C}, \mathrm{pH}=8.5, \text { max activity }= \\
9854 \mathrm{U} / \mathrm{mg}\end{array}$ & $\begin{array}{l}\text { Kozima and Shimizu } \\
(2003)\end{array}$ \\
\hline & Staphylococcus warneri & Palm oil & $\begin{array}{l}\mathrm{T}=40^{\circ} \mathrm{C}, \mathrm{pH}=8, \text { max activity }= \\
1.20 \mathrm{U} / \mathrm{mg}\end{array}$ & Sangeetha et al. (2011) \\
\hline & Burkholderia cepacia & Palm oil & $\begin{array}{l}\mathrm{T}=45^{\circ} \mathrm{C}, \mathrm{pH}=7, \text { max activity }= \\
160 \mathrm{U} / \mathrm{mg}\end{array}$ & Rathi et al. (2002) \\
\hline & Pseudomonas sp. & Groundnut oil & $\begin{array}{l}\mathrm{T}=37^{\circ} \mathrm{C}, \mathrm{pH}=7, \text { max activity }= \\
0.54 \mathrm{U} / \mathrm{ml}\end{array}$ & Ghosh et al. (2005) \\
\hline & $\begin{array}{l}\text { Pseudomonas } \\
\text { aeruginosa }\end{array}$ & Olive oil & $\begin{array}{l}\mathrm{T}=35^{\circ} \mathrm{C}, \mathrm{pH}=9, \text { max activity }= \\
1098 \mathrm{U} / \mathrm{ml}\end{array}$ & Bisht et al. (2012) \\
\hline \multirow{5}{*}{ Fungi } & Fusarium oxysporum & Olive oil & $\begin{array}{l}\mathrm{T}=50^{\circ} \mathrm{C}, \mathrm{pH}=8, \text { max activity }= \\
60 \mathrm{U}\end{array}$ & Prazeres et al. (2006) \\
\hline & Rhizopus oryzae & Palm oil & $\mathrm{T}=55^{\circ} \mathrm{C}, \mathrm{pH}=8-8.5$ & Kharrat et al. (2011) \\
\hline & Fusarium Solani & Palm oil & $\begin{array}{l}\mathrm{T}=40^{\circ} \mathrm{C}, \mathrm{pH}=8, \text { max activity }= \\
1.48 \mathrm{U} / \mathrm{mg}\end{array}$ & Sangeetha et al. (2011) \\
\hline & Geotrichum sp. & Waste cooking oil & $\mathrm{T}=45-50^{\circ} \mathrm{C}, \mathrm{pH}=8$ & Kharrat et al. (2011) \\
\hline & Aspergillus fumigates & Olive oil & $\mathrm{T}=30^{\circ} \mathrm{C}, \mathrm{pH}=8.5-10$ & Rajan et al. (2011) \\
\hline \multirow{3}{*}{ Yeasts } & Candida rugosa & Olive oil & $\begin{array}{l}\mathrm{T}=50^{\circ} \mathrm{C}, \mathrm{pH}=4-9, \text { max activity } \\
=430 \mathrm{U} / \mathrm{g}\end{array}$ & Minovska et al. (2005) \\
\hline & Candida sp. & Waste cooking oil & $\begin{array}{l}\mathrm{T}=50^{\circ} \mathrm{C}, \text { max activity }=222.5 \\
\mathrm{U} / \mathrm{mg}\end{array}$ & Chen et al. (2009) \\
\hline & Candida cylindracea & $\begin{array}{l}\text { Palm oil mill } \\
\text { effluent (POME) }\end{array}$ & $\begin{array}{l}\mathrm{T}=30^{\circ} \mathrm{C}, \mathrm{pH}=6.8, \text { max activity }= \\
4.02 \mathrm{U} / \mathrm{ml}\end{array}$ & Salihu et al. (2011) \\
\hline
\end{tabular}


For the production of enough lipase the media can be optimized by using palm oil as an inducer and lipase activities for both hydrolytic and synthetic catalysis can be compared. Candida rugosa lipase, which exhibited the highest potential for catalyzing the biodiesel production, was further purified and immobilization on various hydrophobic support materials and was found to be the most promising for further development as a biocatalyst for biodiesel synthesis.

Lipase transesterification of triglycerides with an alcohol (alcoholysis) involves a two-step mechanism when looking at a single ester bond. The first step is the hydrolysis of the ester bond and release of the alcohol moiety followed by an esterification with the second substrate. The two steps are represented in equation (1) and (2) (Fjerbaek et al. 2009, Gog et al. 2012).

$$
\mathrm{E}+\mathrm{ESs}_{\mathrm{s}} \leftrightarrow \mathrm{E} . \mathrm{ES}_{\mathrm{s}} \leftrightarrow \mathrm{F} . \mathrm{B}_{\mathrm{p}} \leftrightarrow \mathrm{F}+\mathrm{Bp}_{\mathrm{p}}
$$

Followed by

$$
F+A_{s} \leftrightarrow F . A_{s} \leftrightarrow E . E s_{p} \leftrightarrow E+E s_{p}
$$

Subscripts $s$ and $p$ indicate substrate and product, respectively. For biodiesel, $A_{s}=$ alcohol substrate, $B_{p}=$ product with an alcohol moiety (di or monoglyceride or glycerol), $\mathrm{E}=$ free enzyme, Ess =ester substrate (triglycerides) Esp = FAAE, F = fatty acid (Fjerbaek et al. 2009).

This mechanism conforms to a ping-pong bi bi mechanism as each product is released between additions of the substrate and is the widely accepted mechanism for alcoholysis of triglycerides, although simplifications such as Michaelis-Menten kinetics are applied when fitting to experimental result. An example of an initial rate equation for a ping pong bi bi mechanism can be seen in equation (3)

$$
v_{i}=\frac{v_{m a x}[T G][A]}{K_{m_{i} T G}[A]\left(1+\frac{L A]}{K_{i, A}}+K_{m_{i} A}[T G]+[T G][A]\right.}
$$

Where $v_{i}=$ initial rate; $V_{\max }, K_{m, T G}, K_{i, A}$ and $K_{m, A}=$ kinetic constants; $[T G]$ and $[A]=$ concentration of triglycerides and acyl acceptor, respectively.

In order to have full image of the kinetics of enzymatic alcoholysis of triglycerides, other parameters must also be included such as lipase type, amount of reactant, mass transfer limitations, presence of organic solvent, formation and conversion of intermediates, the temperatures influence on enzyme deactivation or the equilibrium limitation for conversion. Thus, when trying to evaluate or determine the kinetics in such systems all these aspects become important (Gog et al. 2012). In general, lipases perform their catalytic activity in more gentle condition and with a variety of triglyceride substrate, including waste oils and fats with high level of FFA. Furthermore, biodiesel separation and purification is much easier, resulting in a more environmentally friendly process. Fig. 5 shows the transesterification process using lipase as catalyst. 


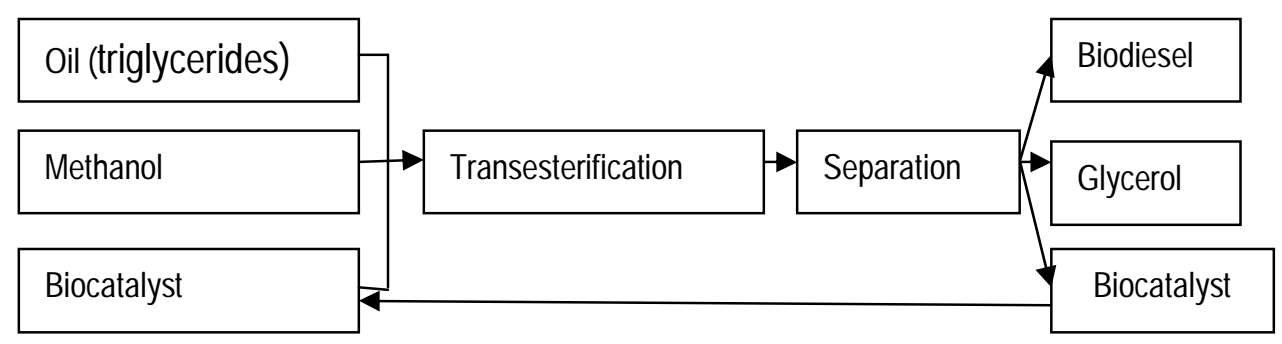

Fig. 5. Transesterification by using lipase as catalyst.

\section{Immobilized lipase in support material}

Use of enzymes as industrial catalysts serve to be beneficial if the whole process is economical and the cost of any process involve the production of the biocatalyst also. Hence recovery of the catalyst for repeated use becomes necessary. Free enzymes are labile and vulnerable to degradation during the process of recovery of the used enzyme. Also, most lipases exhibit low stability and activity in organic media (Lee et al. 2006). The disadvantage could be overcome by the use of immobilization of enzyme. Immobilization improves the stability of the enzyme under the reaction conditions, enhances enzyme activity thus, makes the repeated use of the enzyme feasible, permits the use of enzyme for diverse applications and thus lowers the production cost (Sangeetha et al. 2011). Immobilization provides a better environment for enzyme to act and also offers better product recovery (Lee et al. 2006).

Enzyme immobilization methods are classified as chemical or physical. Chemical methods involve the formation of covalent bonds between functional groups on the enzyme. Chemical methods are sub classified as either non-polymerizing or cross-linking methods. Non-polymerizing methods involve the formation of both enzyme-support bonds only between enzyme and support, but not between individual enzyme molecules, while cross-linking methods allow the formation of both enzyme-support bonds as well as enzyme-enzyme cross-links (Mikkelsen and Corton 2004, Twyman 2005).

Physical immobilization methods do not involve covalent bond formation with the enzyme, so that the native composition of the enzyme remains unaltered. Physical immobilization methods are sub classified as adsorption, entrapment, or encapsulation methods. Adsorption of protein to the surface of a carrier is, in principle, reversible, but careful selection of the carrier material and the immobilization conditions can render desorption negligible. Entrapment of enzyme in a cross-linking polymer is accomplished by carrying out the polymerization reaction in the presence of enzyme; the enzyme becomes trapped in interstitial spaces in the polymer matrices (Winayanuwattikun et al. 2005, Yagiz et al. 2007, Meunier and Legge 2010). Encapsulation of enzymes results in regions of high enzyme concentration is being separated from the bulk solvent system by a semi-permeable membrane, through which substrate, but not enzyme, may diffuse (Li et al. 2011). 
The new method of enzyme immobilization should be able to provide high enzyme loading (close to that of carrier-free enzyme), high retention of activity, and broad reactor configuration. The development of carrier with a predetermined chemical and physical nature, especially suitable geometric properties and binding chemistry, which can bind (or hold) enzyme directly under mild conditions and thus can be used in different reactor configurations. Lipase from different sources has been investigated for their transesterification activity on different support material in Table 2.

Table 2. Yield in transesterification reaction using various support materials and different lipases.

\begin{tabular}{|c|c|c|c|c|c|}
\hline Support material & Alcohol & $\begin{array}{l}\text { Source of } \\
\text { enzyme }\end{array}$ & Feedstock & Yield (\%) & References \\
\hline $\begin{array}{l}\text { Polyacrylonitrile (PAN) } \\
\text { nanofibrous }\end{array}$ & Methanol & P. cepacia & Soybean Oil & 90 & $\begin{array}{l}\text { Winayanuwattikun et al. } \\
(2008)\end{array}$ \\
\hline $\begin{array}{l}\text { Textile cloth with co-fixing } \\
\text { agents }\end{array}$ & Methanol & Candida's lipase & $\begin{array}{l}\text { Waste } \\
\text { cooking oil }\end{array}$ & 91.08 & Chen et al. (2009) \\
\hline Hydro calcite & Methanol & Lipozyme-TL IM & $\begin{array}{l}\text { Waste } \\
\text { cooking oil }\end{array}$ & 92.8 & Yagiz et al. (2007) \\
\hline \multirow{2}{*}{$\begin{array}{l}\text { Microprou's polymeric } \\
\text { matrix (MPPM) }\end{array}$} & \multirow[t]{2}{*}{ Methanol } & \multirow{2}{*}{$\begin{array}{l}\text { Thermomyces } \\
\text { lanuginous }\end{array}$} & Sun flower & 97.0 & \multirow[b]{2}{*}{ Dizge et al. (2009) } \\
\hline & & & $\begin{array}{l}\text { Waste } \\
\text { cooking oil }\end{array}$ & 90.2 & \\
\hline Sepabeads EC-OD & Methanol & C. rugosa & Palm oil & 70.0 & Sangeetha et al. (2011) \\
\hline Chitosan-Glu & Ethanol & C. antartica $B$ & Oleic acid & 75.0 & $\begin{array}{l}\text { Foresti and Ferreira } \\
(2007)\end{array}$ \\
\hline Polyurethane Foam & n-hexane & C. rugosa & Oleic acid & 80.0 & Awang et al. (2007) \\
\hline \multirow{2}{*}{$\begin{array}{l}\text { Zeolite (delaminated } \\
\text { zeolite-ITQ) } \\
\text { Silicate-1(S-1) }\end{array}$} & \multirow[t]{2}{*}{ Methanol } & \multirow{2}{*}{$\begin{array}{l}\text { Rhizomucor } \\
\text { miehei }\end{array}$} & \multirow[t]{2}{*}{ Olive oil } & 92.0 & \multirow[t]{2}{*}{ MacArio et al. (2007) } \\
\hline & & & & 99.0 & \\
\hline \multirow{8}{*}{ Phyllosilicate sol-gel matrix } & \multirow{8}{*}{ Methanol } & \multirow[t]{3}{*}{ P. cepacia } & Palm & 65.0 & \multirow{8}{*}{$\begin{array}{l}\text { Winayanuwattikun et al. } \\
(2008)\end{array}$} \\
\hline & & & Menhaden & 80.0 & \\
\hline & & & Corn & 71.0 & \\
\hline & & \multirow{5}{*}{$\begin{array}{l}\text { Thermomyces } \\
\text { lanuginosa }\end{array}$} & Grease & 78.0 & \\
\hline & & & Palm & 62.0 & \\
\hline & & & Menhaden & 88.0 & \\
\hline & & & Corn & 83.0 & \\
\hline & & & Grease & 89.0 & \\
\hline $\begin{array}{l}\text { Protein-coated micro- } \\
\text { crystals (PCMCs) }\end{array}$ & Tert-butyl alcohol & $\begin{array}{l}\text { Geotrichum sp. } \\
\text { lipase }\end{array}$ & $\begin{array}{l}\text { Waste } \\
\text { cooking oil }\end{array}$ & 64.0 & Yan et al. (2011) \\
\hline Ceramic beads & Methanol & P. cepacia & $\begin{array}{l}\text { Waste } \\
\text { cooking oil }\end{array}$ & 40.0 & Al-Zuhair et al. (2009) \\
\hline \multirow[t]{3}{*}{$\mathrm{SiO}_{2}-\mathrm{PVA}$} & \multirow[t]{3}{*}{ Ethanol } & \multirow{2}{*}{$\begin{array}{l}\text { Burkholderia } \\
\text { cepacia }\end{array}$} & Babassu oil & 100.0 & \multirow{4}{*}{ Da Rós et al. (2010) } \\
\hline & & & Beef tallow & 89.70 & \\
\hline & & \multirow{2}{*}{$\begin{array}{l}\text { Burkholderia } \\
\text { cepacia }\end{array}$} & Babassu oil & 74.13 & \\
\hline $\mathrm{Nb}_{2} \mathrm{O}_{5}$ & Ethanol & & Beef tallow & 40.20 & \\
\hline
\end{tabular}

\section{Nanoparticles as support material in immobilized lipase}

Currently, nanosized magnetic particles used widely in the immobilization of enzyme have received considerable attention. Based on the research of Lee et al. (2007), magnetic $\mathrm{Fe}_{3} \mathrm{O}_{4}$ nanoparticles treated 
with (3-aminopropyl) triethoxysilane were used as immobilization material. The lipase from $T$. lanuginosa was covalently bound to the amino-functionalized magnetic nanoparticles by using glutaraldehyde as a coupling reagent with the activity recovery up to $70 \%$ and the enzyme binding efficiency of $84 \%$. The optimal condition for immobilized lipase was dependent on the immobilization time, temperature, the concentration of glutaraldehyde, and the ratio of lipase to magnetic carrier.

Table 3 shows the nanoparticles used as support material in transesterification. Enzymes immobilized on support materials could catalyze the transesterification of vegetable oils with over $90 \%$ conversion to biodiesel being achieved.

Table 3. The nanoparticles used as support material in transesterification.

\begin{tabular}{|c|c|c|c|c|c|}
\hline Nanoparticle utilized & Material loaded & Feedstock & Parameter process & Yield & References \\
\hline $\mathrm{Fe}_{3} \mathrm{O}_{4}$ nanoparticles & $\begin{array}{l}\text { Lipase from } T . \\
\text { lanuginosa }\end{array}$ & Soybean oil & $\begin{array}{l}50^{\circ} \mathrm{C}, 30 \mathrm{~h},(\mathrm{M}: \mathrm{O}=1: 1) \\
40 \% \text { catalyst }\end{array}$ & $90 \%$ & Xie and $\mathrm{Ma}(2009)$ \\
\hline $\mathrm{Fe}_{3} \mathrm{O}_{4}$ magnetic nanoparticles & T. lanuginosa & Soybean oil & $\begin{array}{l}45^{\circ} \mathrm{C}, 8 \mathrm{~h},(\mathrm{M}: \mathrm{O}=1.5: 1) \\
3 \% \text { catalyst }\end{array}$ & $94 \%$ & Xie and $\mathrm{Ma}(2010)$ \\
\hline Magnetic nanoparticles & $\begin{array}{l}\text { Pseudomonas } \\
\text { cepacia }\end{array}$ & Soybean oil & $40^{\circ} \mathrm{C},(\mathrm{M}: \mathrm{O}=3: 1), 72 \mathrm{~h}$ & $93 \%$ & Mak et al. (2009) \\
\hline $\mathrm{Fe}_{3} \mathrm{O}_{4}$ nanoparticles biocomposite & $\begin{array}{l}\text { Pseudomonas } \\
\text { cepacia }\end{array}$ & Soybean oil & $\begin{array}{l}40^{\circ} \mathrm{C},(\mathrm{O}: \mathrm{DW}: \mathrm{M}: \mathrm{H}=6: 3: 1: 0.2) \\
24 \mathrm{~h}, 0.4 \mathrm{~g} \text { catalyst }\end{array}$ & $>99 \%$ & Wang et al. (2011) \\
\hline Chitosan microspheres & Candida rugosa & Soybean oil & $35^{\circ} \mathrm{C},(\mathrm{M}: \mathrm{O}=4: 1), 30 \mathrm{~h}$ & $87 \%$ & Xie and Wang (2012) \\
\hline Ferric silica nanocomposite & Bulkholderia sp. & Olive oil & $\begin{array}{l}40^{\circ} \mathrm{C},(\mathrm{M}: 0=4: 1), 30 \mathrm{~h} \\
11 \%\end{array}$ & $92 \%$ & Tran et al. (2012a) \\
\hline Ferric silica nanocomposite & Bulkholderia sp. & Microalgal oil & $\begin{array}{l}40^{\circ} \mathrm{C},(\mathrm{M}: \mathrm{O}=61.75) \\
48 \mathrm{~h}, 1203.1 \mathrm{U} \mathrm{g}^{-1}\end{array}$ & $97.25 \%$ & Tran et al. (2012b) \\
\hline
\end{tabular}

Note: $\mathrm{M}=$ methanol, $\mathrm{O}=$ oil, $\mathrm{DW}=$ distilled water, $\mathrm{H}=\mathrm{n}$-hexane

Immobilization of lipase as a catalyst has a great potential for achieving the design and operation of enzymatic biodiesel production on the industrial scale. By using a packed-bed reactor system with lipase$\mathrm{Fe}_{3} \mathrm{O}_{4}$ nanoparticles bio composite catalyst was successfully developed for biodiesel production. The nanoparticles bio composite showed elevated activity and stability in the four-packed-bed reactor with conversion of biodiesel was maintained at the high rate of over $88 \%$ for $192 \mathrm{~h}$. The efficient reuse of the enzyme was realized via a simple and effective immobilization procedure that resulted in a high initial activity without inactivation or inhibitor. The packed-bed reactor system has a great potential for achieving the design and operation of enzymatic biodiesel production on the industrial scale (Wang et al. 2011).

In another study, porcine pancreas lipase was covalently immobilized on the surface of silica-coated magnetite nanoparticles. The diameter of silica-coated magnetite was about $17 \mathrm{~nm}$, and the immobilization process did not change the phase of $\mathrm{Fe}_{3} \mathrm{O}_{4}$. The results showed that the covalent immobilization of lipase on support material improved the thermal, $\mathrm{pH}$ and storage stability. Moreover, kinetic study showed the activation of immobilized enzyme. The enzyme recovery represents the establishment of about $64 \%$ of residual activity after six cycles of washing (Ranjbakhsh et al. 2012). 
The lipase-coated magnetic nanostructures were applied in a reactive extraction process that allowed separation of the products formed during transesterification. It is expected that reactive extraction can directly produce $77 \%$ ethyl oleic (biodiesel) using lower ethanol/triolein ratios compared to $35-40 \%$ purity in the normal stirred reactor with a higher ethanol/triolein ratio. This approach implies a novel and efficient location and use of lipase in column reactors for production of biodiesel (Dussan et al. 2010).

\section{Physicochemical properties of nanomaterial and immobilized lipase}

Immobilization is normally considered to be an important method to improve the stability of enzyme. The morphology of nanoparticles observed using SEM micrograph of coated magnetic particle showed agglomerations because the non-coated magnetic particles were not dispersed in an appropriate substance (Dussan et al. 2010). The pure magnetite was observed to be spherical with nano size (Xie and Wang 2012). The particles diameter is an important factor for support material. Smaller particles have larger surface-tovolume ratios and larger capacity to bind more substance on their surface and product will give less restriction for diffusion.

BET analysis for immobilized Burkholderia sp. shows that the surface area of pure magnetite, silica magnetite, silica-magnetite nanocomposite and alkyl grafted silica-magnetite nanocomposites has a different surface area. Silica-magnetite nanocomposite have a surface area $\left(202 \mathrm{~m}^{2} \mathrm{~g}^{-1}\right)$ and after grafting with the alkyl group at the surface of $\mathrm{Fe}_{3} \mathrm{O}_{4}-\mathrm{SiO}_{2}$, the surface area decreasing $\left(128 \mathrm{~m}^{2} \mathrm{~g}^{-2}\right)$. That would be due to the alkyl group may enter the $\mathrm{Fe}_{3} \mathrm{O}_{4}-\mathrm{SiO}_{2}$ pores, thereby decreasing surface area and smaller pore size (Tran et al. 2012a).

The hydrolytic activity of free and immobilized lipase were measured at various temperatures $\left(35-65^{\circ} \mathrm{C}\right.$ ). The activity of bound and free lipase showed the highest activity at approximately $45^{\circ} \mathrm{C}$. However, the immobilized lipase has higher stability than free lipase. The relative activity of immobilized lipase is $82 \%$ at $55^{\circ} \mathrm{C}$. The optimum hydrolytic activity was observed at $\mathrm{pH} 7.0$ for both lipase. It indicated that immobilization did not change the activity of lipase. Immobilized lipase retained activity when the $\mathrm{pH}$ was higher than $\mathrm{pH}$ optimum. Immobilization method can improve the $\mathrm{pH}$ stability of the lipase, until pH 8.5 with the relative activity 60\% (Xie and Ma 2010).

Furthermore, immobilized lipase can improve the storage stability and catalyst recycling than free lipase. The immobilized lipase conserved more than $64 \%$ of its activity after 21 days while free lipase only $47 \%$. Also in reusing catalyst after 6 cycles, immobilized lipase retained $63 \%$ of its initial activity (Ranjbakhsh et al. 2012).

\section{Kinetic parameters}

Kinetic parameters of free and immobilized lipase were determined from Lineweaver-Burk plots. The measurement of Michaelis-Menten parameters also revealed a considerable improvement of the immobilized lipase. In a study (Ranjbakhsh et al. 2012), $\mathrm{K}_{\mathrm{m}}$ value of immobilized lipase was lower than free lipase, which represents a higher affinity of immobilized lipase to substrates. Certainly with the nano size, magnetic nanoparticles could be imagined to offer lipase molecules a porous surface with a better orientation leading to higher affinity for substrate and more available sites. The result also demonstrated an increase in $V_{\max }$ due to immobilization of lipase. The improvement of $V_{\max }$ may also be due to more efficient conformation of 
immobilized lipase with respect to free lipase. The improvement of kinetic parameters of immobilized lipase can be a good feature for possible industrial application.

Kinetic study showed a dependence of alkyl-grafted- $\mathrm{Fe}_{3} \mathrm{O}_{4}-\mathrm{SiO}_{2}$-lipase on the substrate, the $\mathrm{V}_{\max }$ and $\mathrm{K}_{\mathrm{m}}$ values were estimated at $6251 \mathrm{U} \mathrm{g} \mathrm{g}^{-1}\left(132.4 \mathrm{U} \mathrm{mg}^{-1}\right.$ protein) and $3.65 \mathrm{mM}$, respectively. The $\mathrm{K}_{\mathrm{m}}$ value of alkylgrafted- $\mathrm{Fe}_{3} \mathrm{O}_{4}-\mathrm{SiO}_{2}$-lipase is higher than free lipase but smaller than celite-lipase. The $\mathrm{V}_{\max }$ of alkyl-grafted$\mathrm{Fe}_{3} \mathrm{O}_{4}-\mathrm{SiO}_{2}$-lipase is smaller than free lipase and larger than celite-lipase. It indicated that the structure of enzymes could be rigidified on the surface of celite, thus the blocking of the active site of lipase would probably decrease lipase activity. However, with alkyl-grafted- $\mathrm{Fe}_{3} \mathrm{O}_{4}-\mathrm{SiO}_{2}$-lipase, the binding of lipase on the surface of nanocomposite is multipoint hydrophobic interaction, which may cause the same phenomena as multipoint covalent bonding. The maximum reaction of alkyl-grafted- $\mathrm{Fe}_{3} \mathrm{O}_{4}-\mathrm{SiO}_{2}$-lipase is much higher than celite lipase. This result indicates that hydrophobic interaction is the better approach for immobilization of the lipase (Tran et al. 2012a).

\section{Conclusion}

Nanocrystals and nanomaterials are serving as a novel supports for a catalyst in transesterification reaction. Currently, the use of nanoparticles has emerged as a versatile tool for generating excellent material for the catalyst due to their small size and large surface area and high catalytic activity. Nanoparticles strongly influence the mechanical properties in the material. The nano-magnetic biocatalyst also exhibits as a good catalytic property. Recently, immobilized lipase on nano-magnetic support showed high catalytic activity and advantages of easy separation and reuse. Moreover, nanocomposite grafted with a long alkyl group in order to create affinity for lipase bound on the surface of nanoparticles are shown to be a good matrix for lipase immobilization with high yield of biodiesel and high reusability. Support nanomaterials were prepared by coprecipitation method and also creating a functional group is one of the new trends in immobilization of lipase. Nanocatalyts is a potential material for transesterification reaction and for commercial applications.

\section{Acknowledgment}

The authors are thankful to the Faculty of Industrial Sciences and Technology, Universiti Malaysia Pahang, for funding the research project on biodiesel production.

\section{References}

Al-Zuhair S, Dowaidar A and Kamal H (2009). Dynamic modeling of biodiesel production from simulated waste cooking oil using immobilized lipase. Biochemical Engineering Journal 44: 256-262.

Awang R, Ghazuli MR and Basri M (2007). Immobilization of lipase from Candida rugosa on palm-basedpolyurethane foam as a support material. Journal of Biochemistry and Biotechnology 3: 163-166.

Bajaj A, Lohan P, Jha PN and Mehrotra R (2010). Biodiesel production through lipase catalyzed transesterification: An overview. Journal of Molecular Catalysis B: Enzymatic 62: 9-14.

Balat $\mathrm{M}$ and Balat $\mathrm{H}$ (2010). Progress in biodiesel processing. Applied Energy 87: 1815-1835.

Bisht D, Yadav SK and Darmwal NS (2012). Enhanced production of extracellular alkaline lipase by an improved stran of Pseudomonas aeruginosa MTCC 10,055. American Journal of Applied Sciences 9: 158-167. 
Boey PL, Ganesan S, Maniam GP and Ali DMH (2011a). Ultrasound aided in situ transesterification of crude palm oil adsorbed on spent bleaching clay. Energy Conversion and Management 52: 2081-2084.

Boey PL, Saleh MI, Sapawe N, Ganesan S, Maniam GP and Ali DMH (2011b). Pyrolysis of residual palm oil in spent bleaching clay by modified tubular furnace and analysis of the products by GC-MS. Journal of Analytical and Applied Pyrolysis 91: 199-204.

Boey PL, Maniam GP and Hamid SA (2011c). Performance of calcium oxide as a heterogeneous catalyst in biodiesel production: A review. Chemical Engineering Journal 168: 15-22.

Chanakya HN, Durga MM, Sarada R and Abitha R (2013). Algal biofuel production and mitigation potential in India, 18 (1): 113-136.

Chen Y, Xiao B, Chang J, Fu Y, Lv P and Wang X (2009). Synthesis of biodiesel from waste cooking oil using immobilized lipase in fixed bed reactor. Energy Conversion and Management 50: 668-673.

Da Rós PCM, Silva GAM, Mendes AA, Santos JC and De Castro HF (2010). Evaluation of the catalytic properties of Burkholderia cepacia lipase immobilized on non-commercial matrices to be used in biodiesel synthesis from different feedstocks. Bioresource Technology 101: 5508-5516.

Dias JM, Alvim-Ferraz MCM and Almeida MF (2008). Comparison of the performance of different homogeneous alkali catalysts during transesterification of waste and virgin oils and evaluation of biodiesel quality. Fuel 87: 3572-3578.

Dizge N, Aydiner C, Imer DY, Bayramoglu M, Tanriseven A and Keskinler B (2009). Biodiesel production from sunflower, soybean, and waste cooking oils by transesterification using lipase immobilized onto a novel microporous polymer. Bioresource Technology 100: 1983-1991.

Dudley, B (2017). BP statistical review of world Energy. https://www.bp.com

Dussan KJ, Cardona CA, Giraldo OH, Gutiérrez LF and Pérez VH (2010). Analysis of a reactive extraction process for biodiesel production using a lipase immobilized on magnetic nanostructures. Bioresource Technology 101: 95429549 .

EIA (2011). Anual Energy Outlook 2011 with projections to 2035. US Energy Information Administration, p. 246. Enweremadu CC and Mbarawa MM (2009). Technical aspects of production and analysis of biodiesel from used cooking oil- A review. Renewable and Sustainable Energy Reviews 13: 2205-2224.

Fjerbaek L, Christensen KV and Norddahl B (2009). A review of the current state of biodiesel production using enzymatic transesterification. Biotechnology and Bioengineering 102: 1298-1315.

Foresti ML and Ferreira ML. 2007. Chitosan-immobilized lipases for the catalysis of fatty acid esterifications. Enzyme and Microbial Technology 40: 769-777.

Ghosh M, Bhattacharyya S and Bhattacharyya DK (2005). Production of lipase and phospholipase enzymes from Pseudomonas sp. and their action on phospolipids. Journal of Oleo Science 54: 407-411.

Saxena RK, Ghosh PK, Gupta R, Yadav RP and Davidson S (1996). Microbial lipases: production and applications. Science Progress 72: 199-257.

Gog A, Roman M, Toşa M, Paizs C and Irimie FD (2012). Biodiesel production using enzymatic transesterification Current state and perspectives. Renewable Energy 39: 10-16. 
Gupta N, Rathi P, Singh R, Goswami VK and Gupta R (2005). Single-step purification of lipase from Burkholderia multivorans using polypropylene matrix. Applied Microbiology and Biotechnology 67: 648-653.

Iso M, Chen B, Eguchi M, Kudo T and Shrestha S (2001). Production of biodiesel fuel from triglycerides and alcohol using immobilized lipase. Journal of Molecular Catalysis B 16: 53-58.

Jegannathan KR, Jun-Yee L, Chan ES and Ravindra P (2010). Production of biodiesel from palm oil using liquid core lipase encapsulated in K-carrageenan. Fuel 89: 2272-2277.

Joseph B, Ramteke PW and Thomas G (2008). Cold active microbial lipases: Some hot issues and recent developments. Biotechnology Advances 26: 457-470.

Kharrat N, Ali YB, Marzouk S, Gargouri YT and MahaKarra C (2011). Immobilization of rhizopus oryzae lipase on silica aerogels by adsorption. Process Biochemistry 46: 1083-1089.

Kouzu M and Hidaka JS. 2012. Transesterification of vegetable oil into biodiesel catalyzed by CaO: A review. Fuel 93: 112.

Kozima Y and Shimizu S (2003). Purification and caracterization of the lipase from Pseudomonas fluorescens HU380. Journal of Bioscience and Bioengineering 96: 219-226.

Lam MK, Lee KT and Mohamed AR (2010). Homogeneous, heterogeneous and enzymatic catalysis for transesterification of high free fatty acid oil (waste cooking oil) to biodiesel: a review. Biotechnology Advances 28 : 500-518.

Lam MK, Lee KT and Mohamed AR (2010). Homogeneous, heterogeneous and enzymatic catalysis for transesterification of high free fatty acid oil (waste cooking oil) to biodiesel: A review. Biotechnology Advances 28 : 500-518.

Lee DH, Parli CH, Yeo JM and Kim SW (2006). Lipase immobilization on silica gel using cross-linking method. Journal of Industrial and Engineering Chemistry 12: 777-782.

Leung DYC, Wu X and Leung MKH (2010). A review on biodiesel production using catalyzed transesterification. Applied Energy 87: 1083-1095.

Li SF, Fan YH, Hu JF, Huang YS and Wu WT (2011). Immobilization of Pseudomonas cepacia lipase onto the electrospun PAN nanofibrous membranes for transesterification reaction. Journal of Molecular Catalysis B: Enzymatic 73 (1-4): 98-103.

Liu X, He H, Wang Y, Zhu S and Piao X (2008). Transesterification of soybean oil to biodiesel using CaO as a solid base catalyst. Fuel 87: 216-221.

MacArio A, Giordano G, Setti L, Parise A, Campelo JM, Marinas JM and Luna D (2007). Study of lipase immobilization on zeolitic support and transesterification reaction in a solvent free-system. Journal Biocatalysis and Biotransformation 25: 328-335.

Mak K-H, Yu C-Y, Kuan I-C and Le S-L (2009). Immobilization of Pseudomonas cepacia lipase onto magnetic nanoparticles for biodiesel production, ISESCO Journal of Science and Technology 5: 19-23.

Meunier SM and Legge RL (2010). Evaluation of diatomaceous earth as a support for sol-gel immobilized lipase for transesterification. Journal of Molecular Catalysis B: Enzymatic 62: 53-57.

Mikkelsen SR and Corton E (2004). Bioanalytical Chemistry: Jhon Wiley and Sons, Inc. 61-85 pp. 
Minovska V, Winkelhausen E and Kuzmanova S (2005). Lipase Immobilized by different techniques on various support materials applied in oil hydrolysis. Journal of the Serbian Chemical Society 70: 609-624.

Mobarak-Qamsari E, Kasra-Kermanshahi R and Moosovi-Nejad Z (2011). Isolation and Identification of a novel, lipaseproducing bacterium, Pseudomonas aeruginosa KM110. Iranian Journal of Microbiology 3: 92-98.

Moser BR (2009). Biodiesel production, properties, and feedstocks. In Vitro Cellular and Developmental Biology - Plant, 45: 229-266.

Nordblad M and Adlercreutz P (2008). Efficient enzymatic acrylation through transesterification at controlled water activity. Biotechnology and Bioengineering, 99: 1518-1524.

Petchmala A, Laosiripojana N, Jongsomjit B, Goto M, Panpranot J and Mekasuwandumrong O (2010). Transesterification of palm oil and esterification of palm fatty acid in near- and super-critical methanol with $\mathrm{SO}_{4}$ $\mathrm{ZrO}_{2}$ catalysts. Fuel 89: 2387-2392.

Prazeres JNd, Cruz JAB and Pastore GM (2006). Characterization of alkaline lipase from Fusarium Oxysporum and the effect of different surfactants and detergents on the enzyme activity. Brazilian Journal of Microbiology 37: 505-509.

Rajan A, Kumar DRS and Nair AJ (2011). Isolation of a novel alkaline lipase producing Fungus Aspergillus fumigatus MTCC 9657 from aged and crude rice bran oil and quantification by HPTLC. International Journal of Biological Chemistry 2: 116-26.

Ranjbakhsh E, Bordbar AK, Abbasi M, Khosropour AR and Shams E (2012). Enhancement of stability and catalytic activity of immobilized lipase on silica-coated modified magnetite nanoparticles. Chemical Engineering Journal 179: 272-276.

Rathi P, Goswami VK, Sahai V and Gupta R (2002). Statistical medium optimization and production of a hyperthermostable lipase from Burkholderia cepacia in a bioreactor. Journal of Applied Microbiology 93: 930-936.

Salihu A, Alam MZ, abdulkarim MI and Salleh HM (2011). Suitability of using palm oil mill effluent as a medium for lipase production. African Journal of Biotechnology 10: 2044-2052.

Sangeetha R, Arulpandi I and Geetha A (2011). Bacterial lipases as potential industrial biocatalysts: An overview. Research Journal of Microbiology 6: 1-24.

Semwal S, Arora AK, Badoni RP and Tuli DK (2011). Biodiesel production using heterogeneous catalysts. Bioresource Technology 102: 2151-2161.

Son SM and Kusakabe K (2011). Transesterification of sunflower oil in a countercurrent trickle-bed reactor packed with a $\mathrm{CaO}$ catalyst. Chemical Engineering and Processing: Process Intensification 50: 650-654.

Tan T, Lu J, Nie K, Deng L and Wang F (2010). Biodiesel production with immobilized lipase: A review. Biotechnology Advances 28: 628-634.

Tran DT, Chen CL and Chang JS (2012a). Immobilization of Burkholderia sp. lipase on a ferric silica nanocomposite for biodiesel production. Journal of Biotechnology 158: 112-119.

Tran DT, Yeh KL, Chen CL and Chang JS (2012b). Enzymatic transesterification of microalgal oil from Chlorella vulgaris ESP-31 for biodiesel synthesis using immobilized Burkholderia lipase. Bioresource Technology 108: 119-127.

Twyman RM (2005). Immobilized Enzymes. Enzymes: Elsevier Ltd., 523-529 pp. 
Wang X, Liu X, Zhao C, Ding Y and Xu P (2011). Biodiesel production in packed-bed reactors using lipase-nanoparticle biocomposite. Bioresource Technology 102: 6352-6355.

Winayanuwattikun P, Kaewpiboon C, Piriyakananon K, Tantong S, Thakernkarnkit W, Chulalaksananukul W and Youngvanich T (2008). Potential plant oil feedstock for lipase-catalyzed biodiesel production in Thailand. Biomass and Bioenergy 32: 1279-1286.

Xie W and $\mathrm{Ma} \mathrm{N}$ (2009). Immobilized lipase on $\mathrm{Fe}_{3} \mathrm{O}_{4}$ nanoparticles as biocatalyst for biodiesel production. Energy Fuels 23 (3): 1347-1353.

Xie W and Ma N (2010). Enzymatic transesterification of soybean oil by using immobilized lipase on magnetic nanoparticles. Biomass and Bioenergy 34: 890-896.

Xie W and Wang J (2012). Immobilized lipase on magnetic chitosan microspheres for transesterification of soybean oil. Biomass Bioener 36: 373-380.

Yagiz F, Kazan D and Akin AN (2007). Biodiesel production from waste oils by using lipase immobilized on hydrotalcite and zeolites. Chemical Engineering Journal 134: 262-267.

Yan J, Yan Y, Liu S, Hu J and Wang G (2011). Preparation of cross-linked lipase-coated micro-crystals for biodiesel production from waste cooking oil. Bioresource Technology 102: 4755-4758.

Yiu HHP and Keane MA (2012). Enzyme-magnetic nanoparticle hybrids: new effective catalysts for the production of high value chemicals. Journal of Chemical Technology and Biotechnology 87: 583-594. 
